Article

\title{
Surface Characterization, Corrosion Resistance and in Vitro Biocompatibility of a New Ti-Hf-Mo-Sn Alloy
}

\author{
Raluca Ion ${ }^{1, \dagger}{ }^{+}$, Silviu Iulian Drob ${ }^{2,+}$, Muhammad Farzik Ijaz ${ }^{3}$, Cora Vasilescu ${ }^{2}$, Petre Osiceanu ${ }^{2}$, \\ Doina-Margareta Gordin ${ }^{3}$, Anisoara Cimpean ${ }^{1, *}$ and Thierry Gloriant ${ }^{3}$ \\ 1 Department of Biochemistry and Molecular Biology, University of Bucharest, 91-95 Spl. Independentei, \\ Bucharest 050095, Romania; rciubar@yahoo.com \\ 2 Institute of Physical Chemistry "Ilie Murgulescu”, Romanian Academy, Bucharest 060021, Romania; \\ sidrob.icf@gmail.com (S.I.D.); cora_vasilescu@yahoo.com (C.V.); petre.osiceanu@yahoo.com (P.O.) \\ 3 Institut des Sciences Chimiques de Rennes, UMR CNRS 6226, INSA Rennes, \\ 20 avenue des Buttes de Coësmes, Rennes 35708, France; farzik98@gmail.com (M.F.I.); \\ doina.gordin@insa-rennes.fr (D.-M.G.); thierry.gloriant@insa-rennes.fr (T.G.) \\ * Correspondence: anisoara.cimpean@bio.unibuc.ro; Tel.: +40-21-3181575 (ext. 106) \\ + These authors contributed equally to this work.
}

Academic Editors: Juergen Stampfl and Arne Berner

Received: 6 August 2016; Accepted: 28 September 2016; Published: 4 October 2016

\begin{abstract}
A new superelastic Ti-23Hf-3Mo-4Sn biomedical alloy displaying a particularly large recovery strain was synthesized and characterized in this study. Its native passive film is very thick $(18 \mathrm{~nm})$ and contains very protective $\mathrm{TiO}_{2}, \mathrm{Ti}_{2} \mathrm{O}_{3}, \mathrm{HfO}_{2}, \mathrm{MoO}_{2}$, and $\mathrm{SnO}_{2}$ oxides (XPS analysis). This alloy revealed nobler electrochemical behavior, more favorable values of the corrosion parameters and open circuit potentials in simulated body fluid in comparison with commercially pure titanium (CP-Ti) and Ti-6Al-4V alloy taken as reference biomaterials in this study. This is due to the favorable influence of the alloying elements $\mathrm{Hf}, \mathrm{Sn}, \mathrm{Mo}$, which enhance the protective properties of the native passive film on alloy surface. Impedance spectra showed a passive film with two layers, an inner, capacitive, barrier, dense layer and an outer, less insulating, porous layer that confer both high corrosion resistance and bioactivity to the alloy. In vitro tests were carried out in order to evaluate the response of Human Umbilical Vein Endothelial Cells (HUVECs) to Ti-23Hf-3Mo-4Sn alloy in terms of cell viability, cell proliferation, phenotypic marker expression and nitric oxide release. The results indicate a similar level of cytocompatibility with HUVEC cells cultured on Ti-23Hf-3Mo-4Sn substrate and those cultured on the conventional CP-Ti and Ti-6Al-4V metallic materials.
\end{abstract}

Keywords: biomedical alloy; native passive film; electrochemical behavior; corrosion resistance; endothelial cell behavior

\section{Introduction}

Multifunctional $\beta$ Ti-based alloys elaborated with biocompatible alloying elements have become an important field of investigation for biomedical applications due to their advantageous characteristics, such as low modulus and high elastic recovery [1-4]. Over the years, several new kinds of metastable $\beta$ Ti-based alloys with superior superelastic properties have been introduced owing to distinct compositional modifications and/or targeted alloy design. For example, metastable $\beta$ Ti-Nb and $\beta$ Ti-Zr based alloys have been found to exhibit large superelastic recovery strain at room temperature through reversible stress-induced martensitic transformation between parent $\beta$ phase (body centered cubic structure) and martensite $\alpha^{\prime \prime}$ phase (orthorhombic structure) [2,5-7]. 
In a previous work [8], a new Ti-23Hf-3Mo-4Sn superelastic alloy was elaborated and characterized. With this alloy composition, outstanding combination of high strength ( 1 GPa), low Young's modulus ( $55 \mathrm{GPa}$ ) and large recovery strain of about $4 \%$ were achieved. These mechanical properties make this newly developed Ti-23Hf-3Mo-4Sn alloy very promising for the development of new biocompatible devices such as superelastic self-expanding stents. One important feature for biomedical devices is the corrosion resistance, which must necessarily be high in order to avoid the release of metallic products and to prevent inflammatory responses. The corrosion resistance of $\mathrm{Ti}$ is well-known; its thin native passive film ensures protection on a very large potential and $\mathrm{pH}$ range [9]. Hafnium [9] has a native passive film consisting of $\mathrm{HfO}_{2}$ oxide; this oxide is very resistant from $\mathrm{pH} \approx 4$ to $\mathrm{pH} \approx 16$ in a potential domain comprising $-1.8 \mathrm{~V}$ and $+1.8 \mathrm{~V}$ (vs. SHE); thus, it is an improvement of the protective capacity is expected by alloying $\mathrm{Hf}$ with Ti. Tin [9] is immune and then is passive for the whole $\mathrm{pH}$ range (from -2 till 16) and a large potential domain; its resistant $\mathrm{SnO}_{2}$ will reinforce the passive film on Ti surface by alloying. Molybdenum [9] has a large immunity potential range (from $-2 \mathrm{~V}$ till $-0.4 \mathrm{~V}$ vs. SHE) and will shift the corrosion potentials of its alloys with Ti to nobler direction. Thus, alloying Ti with Hf, Sn and Mo can lead to excellent corrosion resistance [10]. There is only little information about the titanium binary alloys with hafnium. Jeong et al. [11] applied nanotubes on binary Ti-xHf ( $x=10 \%, 20 \%, 30 \%$ and $40 \%)$ alloy surfaces for dental use and the best behavior could be observed for the Ti-20Hf alloy. Ternary titanium alloy with Ta and Hf and Ti-35Ta-xHf ( $x=3-15 \mathrm{wt} \%)$ were coated with nanotubular structures of TiN/ZrN to increase their biocompatibility [12]. A new quaternary equiatomic Hf-25Sc-25Ti-25Zr alloy [13] was processed by compression deformation and annealed and showed a high thermal stability.

The main aim of this study is to characterize, for the first time, a novel Ti-23Hf-3Mo-4Sn alloy in terms of its native passive film composition and thickness (by X-ray photoelectron spectroscopy-XPS); the electrochemical stability and corrosion resistance (by cyclic and linear polarization, electrochemical impedance spectroscopy-EIS) of the interface between the new alloy and simulated body fluid-SBF, its biocompatibility by in vitro tests with Human Umbilical Vein Endothelial Cells (HUVECs), in terms of cell viability and proliferation, phenotypic marker expression and nitric oxide release. The values of all the electrochemical and corrosion parameters prove a nobler electrochemical behavior and a higher protective capacity of the new superelastic Ti-23Hf-3Mo-4Sn alloy by comparison with commercially pure titanium (CP-Ti, grade 2) and Ti-6Al-4V (grade $5 \mathrm{ELI}$ ) alloy. CP-Ti and Ti-6Al-4V medical grades were chosen as control biomaterials in this study because they are regularly used for cardiovascular devices such as pacemakers, heart valves, catheters, vascular clips. Endothelial cells in contact with the three analyzed metallic samples display excellent growth capacity and characteristic phenotype and functions. Furthermore, this alloy was previously shown to possess an equiaxed $\beta$-phase grain microstructure and a perfect superelastic behavior with a particularly large recovery strain of about $4 \%[8]$.

\section{Results and Discussion}

\subsection{Composition and Thickness of the Alloy Native Passive Film}

Before analysis, the roughness of the mirror polished samples was evaluated by atomic force microscopy (AFM). An example of AFM map is presented in Figure 1. From the different AFM maps realized, a uniform roughness was obtained and the roughness value, Ra, was measured to be $14 \mathrm{~nm} \pm 3 \mathrm{~nm}$.

The XPS survey spectrum shown in Figure 2 reveals that the thickness of the native passive film is $\sim 18.0 \pm 1.0 \mathrm{~nm}$ [14]. Quantitative assessment indicates that the cation relative concentrations are $\mathrm{Ti}=69.2 \% ; \mathrm{Hf}=23.5 \% ; \mathrm{Mo}=1.8 \% ; \mathrm{Sn}=5.5 \%$. It results that the surface is depleted of Mo and enriched in Sn (Mo diffusion from surface to the subsurface region is accompanied by segregation of $\mathrm{Sn}$ to the outermost surface layer). 


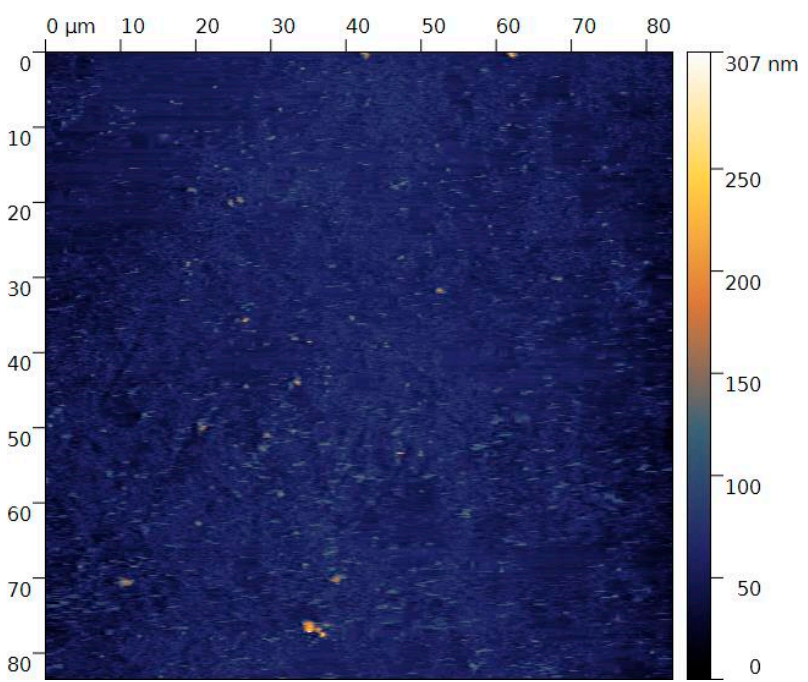

Figure 1. Example of AFM map (tapping mode) realized for the evaluation of the superficial roughness.

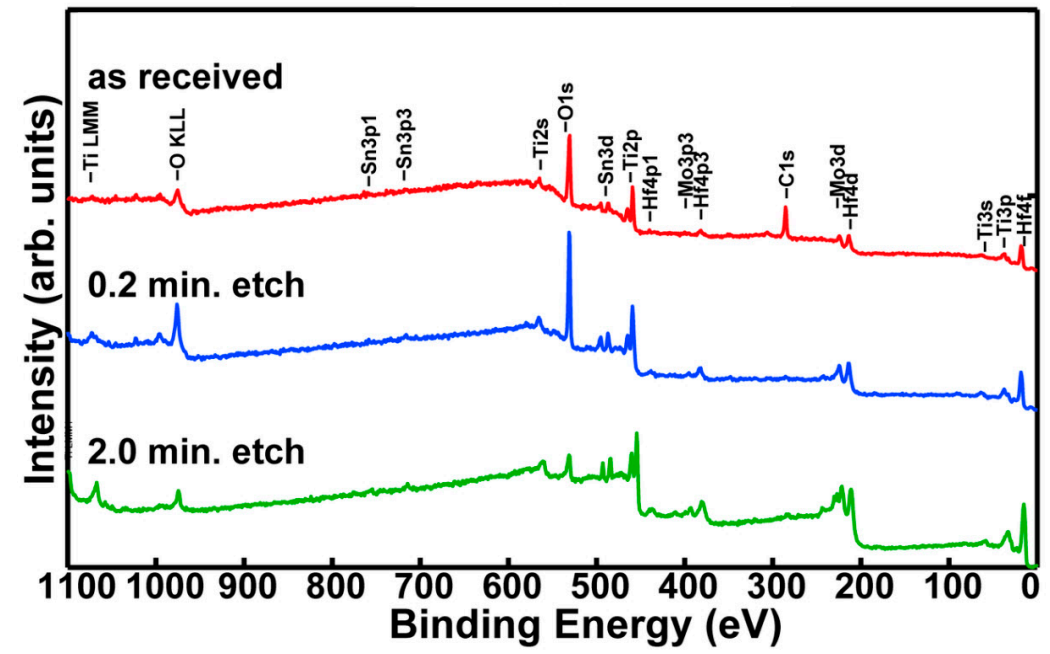

Figure 2. The XPS wide scan/surveys superimposed spectra for the as received Ti-23Hf-3Mo-4Sn alloy and after 0.2 and 2 min etching.

High-resolution spectra (Figure 3) were collected in order to highlight the chemistry of the detected elements $[15,16]$, while Tables 1 and 2 summarize the associated quantitative assessments.
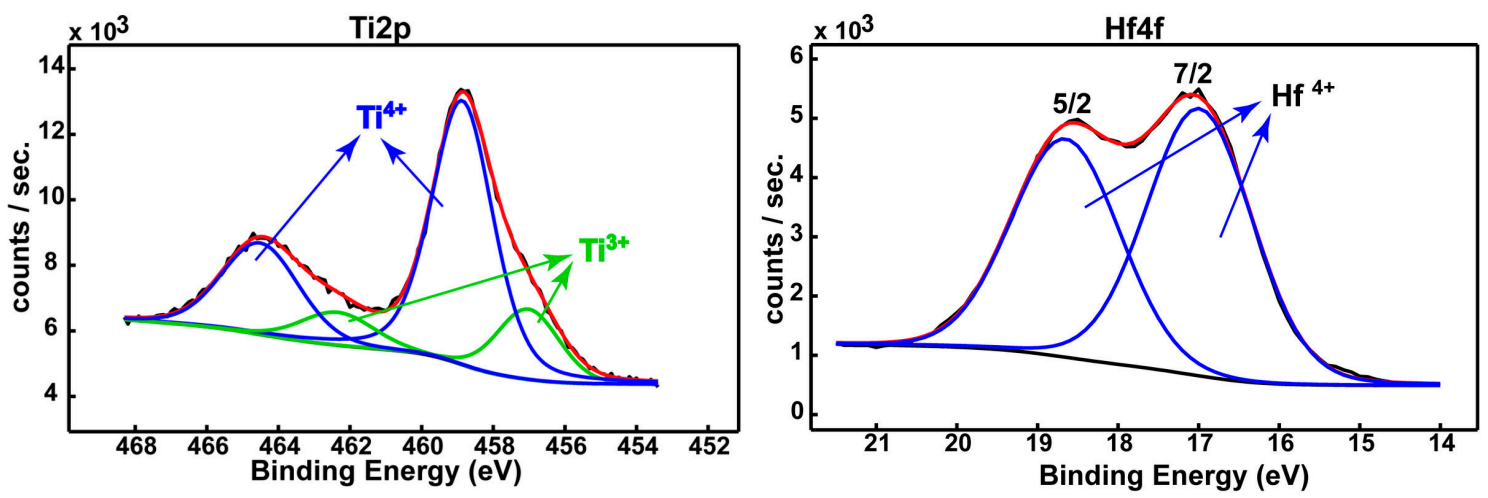

Figure 3. Cont. 

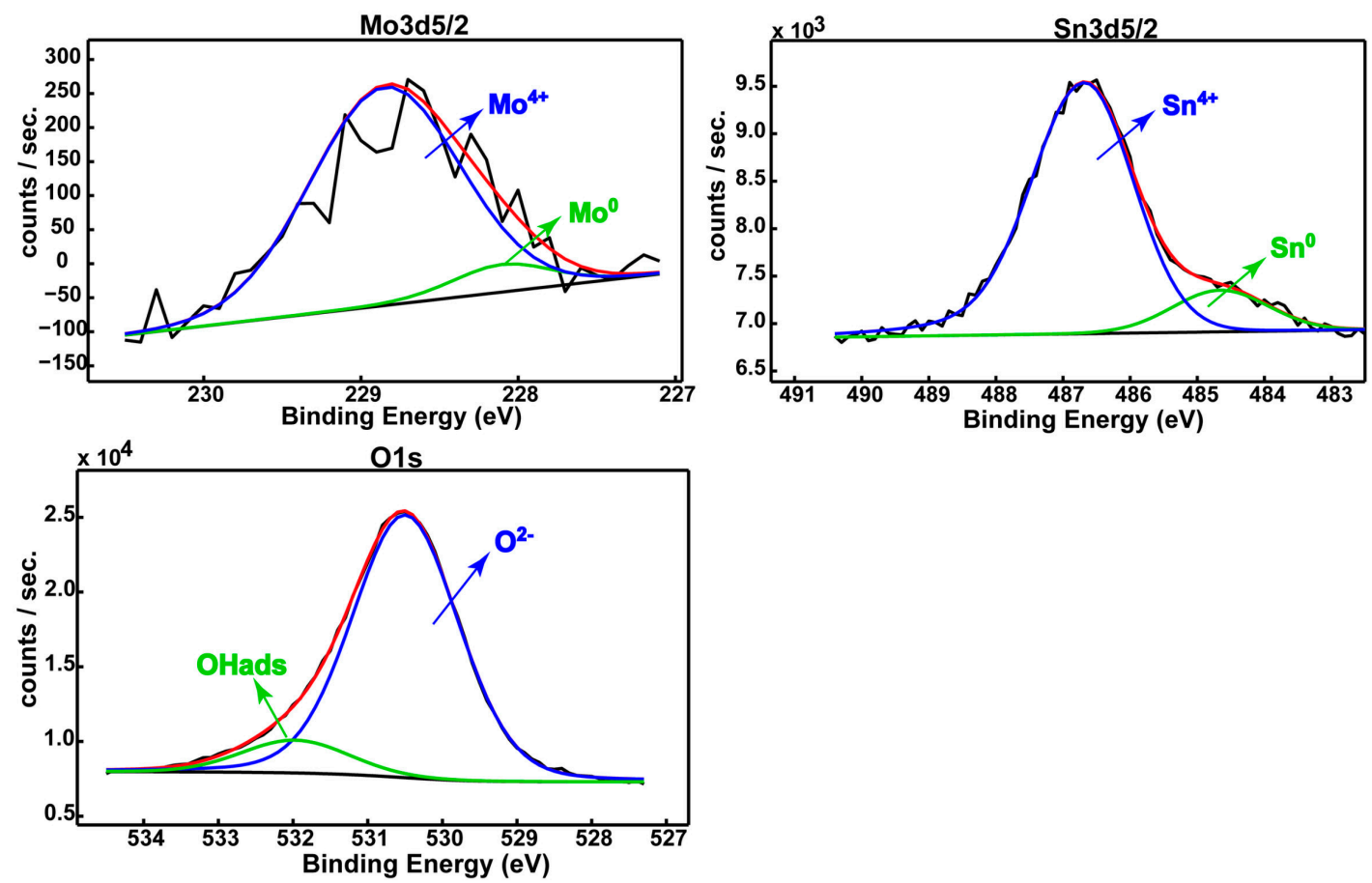

Figure 3. Deconvoluted spectra for the constitutive elements of the native passive film existing on the Ti-23Hf-3Mo-4Sn alloy surface.

Table 1. XPS data of Ti-23Hf-3Mo-4Sn alloy surface chemistry: the binding energies vs. ions.

\begin{tabular}{ccccc}
\hline \multicolumn{5}{c}{ Ions } \\
\hline $\mathrm{O} 1 \mathrm{~s}$ & $\mathrm{Ti} 2 \mathrm{p}_{3 / 2}$ & $\mathrm{Hf} 4 \mathrm{f}_{7 / 2}$ & Mo $3 \mathrm{~d}_{5 / 2}$ & $\mathrm{Sn} 3 \mathrm{~d}_{5 / 2}$ \\
\hline \multicolumn{5}{c}{ Binding energies (eV)/Ions } \\
\hline $530.5 / \mathrm{O}^{2-}$ & $457.0 / \mathrm{Ti}^{3+}$ & $17.0 / \mathrm{Hf}^{4}$ & $228.1 / \mathrm{Mo}^{0}$ & $484.7 / \mathrm{Sn}^{0}$ \\
$531.9 / \mathrm{OH}$ ads & $458.9 / \mathrm{Ti}^{4+}$ & & $228.8 / \mathrm{Mo}^{4+}$ & $486.7 / \mathrm{Sn}^{4+}$ \\
\hline
\end{tabular}

Table 2. XPS data of Ti-23Hf-3Mo-4Sn alloy surface chemistry: relative concentration (\%) vs. oxidation states.

\begin{tabular}{cccc}
\hline \multicolumn{4}{c}{ Ions } \\
\hline $\mathrm{Ti}$ & $\mathrm{Hf}$ & $\mathrm{Mo}$ & $\mathrm{Sn}$ \\
\hline \multicolumn{4}{c}{ Concentration (\%)/Oxidation States } \\
\hline $21.3 / \mathrm{Ti}^{3+}$ & $100.0 / \mathrm{Hf}^{4+}$ & $8.4 / \mathrm{Mo}^{0}$ & $13.0 / \mathrm{Sn}^{0}$ \\
$78.7 / \mathrm{Ti}^{4+}$ & & $91.6 / \mathrm{Mo}^{4+}$ & $87.0 / \mathrm{Sn}^{4+}$ \\
\hline
\end{tabular}

The deconvoluted spectra identified the constituent elements of the native passive film (Ti 2p, $\mathrm{Hf} 4 \mathrm{f}, \mathrm{Mo} \mathrm{3d}, \mathrm{Sn} 3 \mathrm{~d}$, and O 1s) after their binding energies (Table 1). Table 2 evidenced that: Ti occurs as a mixture of $\mathrm{TiO}_{2}(78.7 \%)$ and $\mathrm{Ti}_{2} \mathrm{O}_{3}(21.3 \%) ; \mathrm{Hf}$ is fully oxidized $\left(\mathrm{HfO}_{2}\right)$; Mo shows a mixture of $\mathrm{MoO}_{2}(91.6 \%)$ and metallic $\mathrm{Mo}(8.4 \%)$; Sn exhibits a mixture of $\mathrm{SnO}_{2}(87.0 \%)$ and metallic $\mathrm{Sn}(13.0 \%)$. The thicknesses of the individual oxides are quite different, $\mathrm{HfO}_{2}$ being the main contributor to the overall thickness of the film on the new alloy surface.

XPS results indicate that the native passive film on the new Ti-23Hf-3Mo-4Sn alloy surface is thicker, more compact, reinforced, and contains additional $\mathrm{HfO}_{2}, \mathrm{MoO}_{2}, \mathrm{SnO}_{2}$ protective oxides compared to CP-Ti and Ti-6Al-4V alloy. Thus, it is expected that the new alloy has improved protective properties in comparison with the reference biomaterials. 


\subsection{Electrochemical Behavior of the Ti-23Hf-3Mo-4Sn Alloy}

\subsubsection{Electrochemical Behavior from Cyclic Potentiodynamic Curves}

The cyclic potentiodynamic curves presented in Figure 4 evince a typical passive behavior both for $\mathrm{CP}-\mathrm{Ti}$, Ti-6Al-4V and the new Ti-23Hf-3Mo-4Sn alloy. These curves did not display hysteresis loops, namely, no local corrosion took place on the surface of the three studied materials; this fact was confirmed by the microscopic observations. As shown in Table 3, more favorable values of all the electrochemical parameters were obtained for the newly developed alloy: more electropositive values of the corrosion, $E_{c o r r}$, and passivation, $E_{p}$ potentials due to the effect of the galvanic couple of the alloying elements; lower values of the tendency to passivation; $\left|\mathrm{E}_{\mathrm{corr}}-\mathrm{E}_{\mathrm{p}}\right|$ and passive current density; $i_{p}$ which indicates a more rapid, easier, better passivation and a more resistant passive film that prevents the active dissolution of the alloy substrate, respectively $[17,18]$. The values of all the electrochemical parameters prove a nobler electrochemical behavior of the new alloy than that of CP-Ti and Ti-6Al-4V alloy [19]. This behavior is ascribed to the presence of a thicker native passive film $(18.0 \mathrm{~nm} \pm 1.0 \mathrm{~nm})$ on its surface as compared with that of CP-Ti $(1.3-3.7 \mathrm{~nm})$ [20] and Ti-6Al-4V $(5 \mathrm{~nm})$ [21] alloy; in addition, besides $\mathrm{Ti}_{2} \mathrm{O}_{3}, \mathrm{TiO}_{2}$ oxides, this film contains $\mathrm{HfO}_{2}, \mathrm{SnO}_{2}$ and $\mathrm{MnO}_{2}$ protective oxides that thicken and compact it, conferring very good stability in SBF (see Section 2.1).

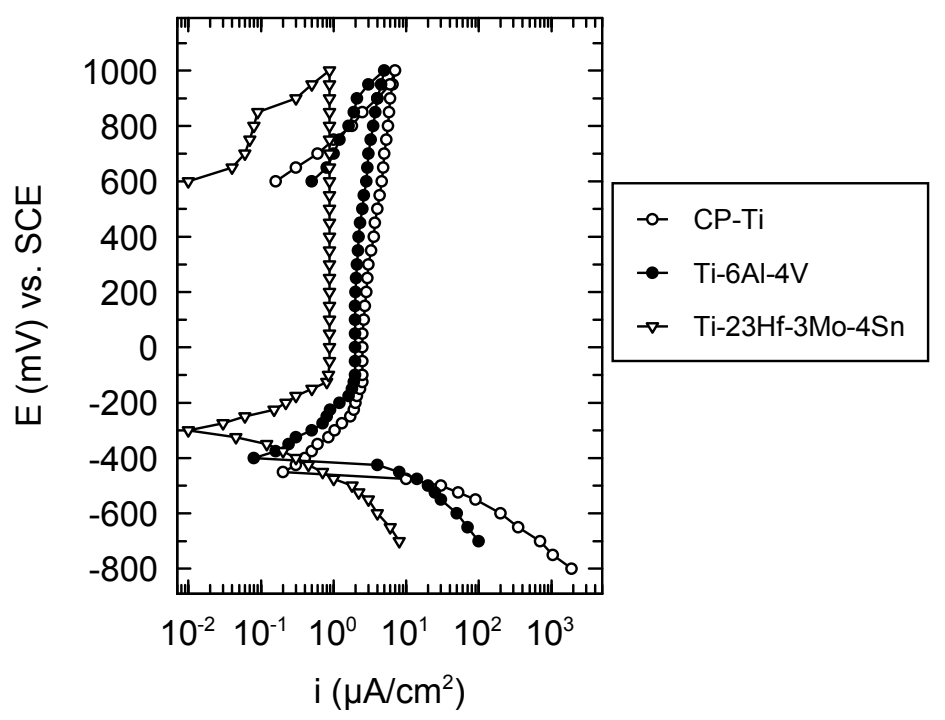

Figure 4. Cyclic potentiodynamic curves for CP-Ti, Ti-6Al-4V and Ti-23Hf-3Mo-4Sn alloys in SBF at $37^{\circ} \mathrm{C}$.

Table 3. Electrochemical parameters for $\mathrm{CP}-\mathrm{Ti}$, Ti-6Al-4V and Ti-23Hf-3Mo-4Sn alloys obtained from cyclic potentiodynamic polarization tests in $\mathrm{SBF}$ at $37^{\circ} \mathrm{C}$.

\begin{tabular}{cccccc}
\hline Material & $\mathrm{E}_{\text {corr }}(\mathbf{m V})$ & $\mathrm{E}_{\mathbf{p}}(\mathbf{m V})$ & $\boldsymbol{\Delta} \mathrm{E}_{\mathbf{p}}(\mathbf{m V})$ & $\left|\mathrm{E}_{\text {corr }}-\mathrm{E}_{\mathbf{p}}\right| \mathbf{( \mathbf { m V } )}$ & $\mathbf{i}_{\mathbf{p}}\left(\boldsymbol{\mu} \mathbf{A} / \mathbf{c m}^{\mathbf{2}}\right)$ \\
\hline CP-Ti & -470 & -150 & $>1000$ & 320 & 2.512 \\
Ti-6Al-4V & -400 & -150 & $>1000$ & 250 & 1.995 \\
Ti-23Hf-3Mo-4Sn & -300 & -100 & $>1000$ & 200 & 0.873 \\
\hline
\end{tabular}

\subsubsection{Corrosion Resistance from Linear Polarization Tafel Representations}

The corrosion parameters $\mathrm{i}_{\text {corr }}$ (corrosion current density) and $\mathrm{V}_{\text {corr }}$ (corrosion rate) (Table 4) for the newly developed alloy have lower values of about 8-9 times than those for CP-Ti and Ti-6Al-4V alloys, a fact that demonstrates a more resistant passive film on the new alloy surface. The total quantity of ions released into SBF by the new alloy is lower than that of the reference materials, showing a much reduced toxicity. In addition, polarization resistance, $\mathrm{Rp}$, for the novel alloy has a higher value of 
about 6-9 times than those of CP-Ti and Ti-6Al-4V alloys due to more protective passive film existing on the new alloy surface $[17,18]$. The new alloy is placed in the "Perfect Stable" resistance class [22], a fact that depicts a high resistance to corrosion [23]. The higher values of the anodic, $\beta_{\mathrm{a}}$ Tafel slopes than those of the cathodic, $\beta_{\mathrm{c}}$ Tafel slopes reflect the anodic control of the processes from the interface, namely, the existence of the passive layer [24] in addition, to the values of the cathodic $\beta_{c}$ Tafel slopes around $-115 \mathrm{mV} / \mathrm{dec}$. Tafel-like behavior signifies that the cathodic reaction of hydrogen reduction does not depend on the alloy composition [24]. All corrosion parameters confirm a higher protective capacity of the new alloy passive film in comparison with those of the commercial materials CP-Ti and Ti-6Al-4V alloys.

Table 4. Corrosion parameters for CP-Ti, Ti-6Al-4V and Ti-23Hf-3Mo-4Sn alloys obtained from potentiodynamic linear polarization tests in $\mathrm{SBF}$ at $37^{\circ} \mathrm{C}$.

\begin{tabular}{cccccccc}
\hline Material & $\begin{array}{c}\mathbf{i}_{\text {corr }} \\
\left(\mu \mathbf{A} / \mathbf{c m}^{\mathbf{2}}\right)\end{array}$ & $\begin{array}{c}\mathbf{V}_{\text {corr }} \\
(\mu \mathbf{m} / \mathbf{Y})\end{array}$ & $\begin{array}{c}\text { Ion Release } \\
\left(\mathbf{n g} / \mathbf{c m}^{\mathbf{2}}\right)\end{array}$ & $\begin{array}{c}\text { Resistance } \\
\text { Class }\end{array}$ & $\begin{array}{c}\mathbf{R}_{\mathbf{p}} \\
\left(\mathbf{k} \mathbf{\Omega} \cdot \mathbf{c m}^{\mathbf{2}}\right)\end{array}$ & $\begin{array}{c}\boldsymbol{\beta}_{\mathbf{a}} \\
(\mathbf{m V} / \mathbf{d e c})\end{array}$ & $\begin{array}{c}\boldsymbol{\beta}_{\mathbf{c}} \\
(\mathbf{m V} / \mathbf{d e c})\end{array}$ \\
\hline CP-Ti & 0.552 & 5.051 & 513.18 & VS & 20.52 & 180 & -119 \\
Ti-6Al-4V & 0.492 & 4.502 & 457.40 & VS & 30.75 & 189 & -118 \\
Ti-23Hf-3Mo-4Sn & 0.061 & 0.649 & 65.93 & PS & 198.18 & 191 & -115 \\
\hline
\end{tabular}

VS-Very Stable; PS-Perfect Stable.

\subsubsection{Electrochemical Behavior from EIS}

Nyquist spectra (Figure 5a) are represented by large, incomplete, depressed semicircles, which show a capacitive behavior, and a passive film like an insulator [25-27]. The semicircle diameters increase in the order: $\mathrm{Ti}<\mathrm{Ti}-6 \mathrm{Al}-4 \mathrm{~V}<\mathrm{Ti}-23 \mathrm{Hf}-3 \mathrm{Mo}-4 \mathrm{Sn}$, namely, the passive film on the new alloy surface possesses the highest insulating, capacitive, protective properties, confirming the XPS results which describe the thickest film.

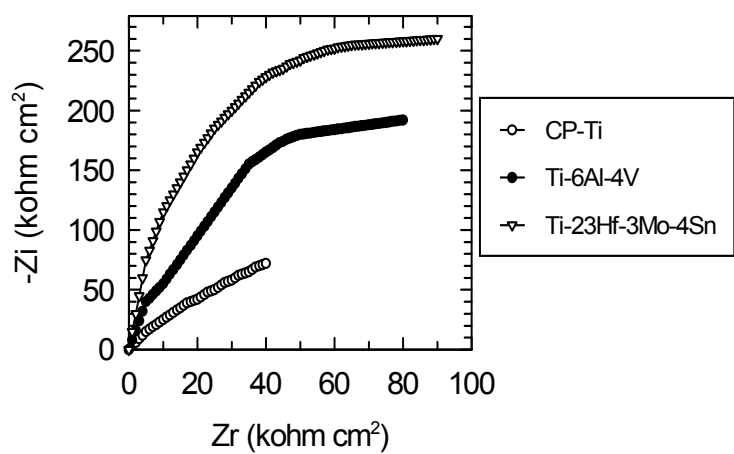

(a)

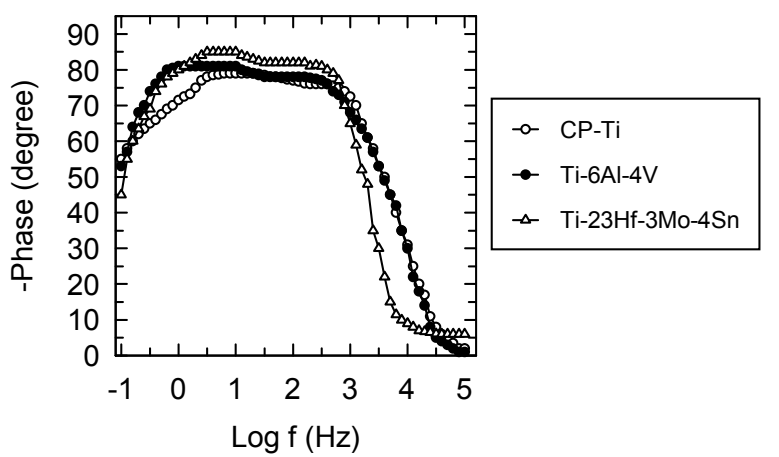

(b)

Figure 5. Nyquist and Bode phase angle spectra for CP-Ti, Ti-6Al-4V and Ti-23Hf-3Mo-4Sn alloys in SBF at $37^{\circ} \mathrm{C}$ : (a) Nyquist plots; and (b) Bode phase angle plots.

Bode phase angle spectra (Figure 5b) exhibit two phase angles: in the low frequency range, higher phase angles than those from the middle frequency range can be observed. The values of the first phase angle vary between $-79^{\circ}$ for $\mathrm{Ti}$, to $-81^{\circ}$ for Ti-6Al-4V alloy, to $-85^{\circ}$ for Ti-23Hf-3Mo-4Sn alloy. The highest phase angle for the new alloy denotes the highest capacitive, the most protective passive film [25-31]; this fact is sustained by the XPS depth profiling analysis that indicates a very thick $(18 \mathrm{~nm})$ native passive film. It is known that the thickest passive film assures the highest protection, corrosion resistance [32]. The second, lower angle from the middle frequency range has values of $-76^{\circ}$ for $\mathrm{Ti}$, $-78^{\circ}$ for Ti-6Al-4V alloy and $-82^{\circ}$ for Ti-23Hf-3Mo-4Sn alloy, indicating a defective capacitor with some pores which permit transfer processes from the substrate to solution and from the solution to substrate. Thus, these two phase angles characterize a passive film with two layers [25-28]: the highest 
phase angle represents the inner, capacitive, barrier, compact layer and the lower one illustrates the outer, less protective, porous layer that confers bioactivity to the alloy [30,31].

The EIS results were modeled with an electric equivalent circuit consisting of two time constants (Figure 6) as other many authors [25-31,33-36]. The electrical parameters are a resistor, $\mathrm{R}$, to show the film conductance and a capacitor, $\mathrm{CPE}$, for the film dielectric properties. The first time constant associated with the high phase angle describes the inner, dense, barrier layer and is composed by the barrier layer resistance, $R_{b}$ and capacitance $C P E_{b}$. The second time constant is related to the lower phase angle that represents the outer, less insulating, less resistant, porous layer and is formed by the porous layer resistance, $R_{p}$ and capacitance, $C P E_{p}$ (the constant phase element, $C P E$ was used instead of capacitance, $\mathrm{C}$ to illustrate the non-ideal capacitor).

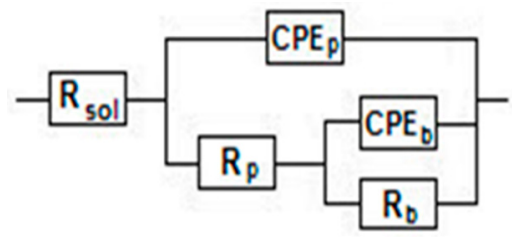

Figure 6. Fitted electric equivalent circuit.

Fitting parameters from Table 5 have more favorable values for the new Ti-23Hf-3Mo-4Sn alloy, indicating that its passive film is more resistant. This fact confirms the XPS results that revealed a thicker, denser, more compact passive film on the new alloy surface. The inner, barrier layer resistance $R_{b}$ has higher values with two orders of magnitude than the resistance of the outer, porous layer $R_{p}$, denoting that the resistance of the passive film is conferred by the inner, compact layer $[25,26]$. The barrier layer capacitance, $\mathrm{CPE}_{\mathrm{b}}$, is one order of magnitude lower than that of the porous layer, $\mathrm{CPE}_{\mathrm{p}}$, suggesting that the inner layer is thicker than the outer layer [25]. The frequency independent parameter, $n$, shows the non-uniform current distribution on the surface due to its roughness and homogeneity [25]. For the barrier layer, the $\mathrm{n} 1$ values are much closer to 1, namely, an about ideal capacitor; for the porous layer, $\mathrm{n} 2$ values are lower, i.e., this layer has a less insulating behavior.

Table 5. Fitting parameters of the electric equivalent circuit for CP-Ti, Ti-6Al-4V and Ti-23Hf-3Mo-4Sn alloys in SBF at $37^{\circ} \mathrm{C}$.

\begin{tabular}{|c|c|c|c|c|c|c|c|}
\hline Material & $\begin{array}{c}R_{s} \\
\left(\Omega \cdot \mathrm{cm}^{2}\right)\end{array}$ & $\begin{array}{c}R_{b} \\
\left(\Omega \cdot \mathrm{cm}^{2}\right)\end{array}$ & $\underset{\left(S \cdot s^{n} \mathrm{~cm}^{-2}\right)}{\mathrm{CPE}_{\mathrm{b}}}$ & n1 & $\begin{array}{c}R_{p} \\
\left(\Omega \cdot \mathrm{cm}^{2}\right)\end{array}$ & $\begin{array}{c}\mathrm{CPE}_{\mathrm{p}} \\
\left(\mathrm{S} \cdot \mathrm{s}^{\mathrm{n}} \mathrm{cm}^{-2}\right)\end{array}$ & $\mathrm{n} 2$ \\
\hline CP-Ti & 12.4 & $8.3 \times 10^{5}$ & $9.4( \pm 0.1) \times 10^{-6}$ & 0.95 & $7.2 \times 10^{3}$ & $1.8( \pm 0.1) \times 10^{-5}$ & 0.88 \\
\hline Ti-6Al-4V & 13.6 & $9.5 \times 10^{5}$ & $9.2( \pm 0.2) \times 10^{-6}$ & 0.97 & $1.8 \times 10^{4}$ & $1.1( \pm 0.1) \times 10^{-5}$ & 0.90 \\
\hline Ti-23Hf-3Mo-4Sn & 14.5 & $1.7 \times 10^{6}$ & $8.1( \pm 0.1) \times 10^{-6}$ & 0.99 & $1.9 \times 10^{4}$ & $0.9( \pm 0.1) \times 10^{-5}$ & 0.91 \\
\hline
\end{tabular}

\subsubsection{Long-Term Corrosion Resistance from Monitoring of the Open Circuit Potentials}

The open circuit potentials $\left(\mathrm{E}_{\mathrm{oc}}\right)$ were monitored for 1000 exposure hours of the studied materials exposed to the aggressive action of SBF (Figure 7).

The open circuit potentials for $\mathrm{CP}-\mathrm{Ti}$ have the most electronegative values from the initial to the final experimental time; the slow increase of $E_{\text {oc }}$ values occurred in the first $50 \mathrm{~h}$ and then about stable values of $-250 \mathrm{mV}$ (vs. SCE) were maintained; these facts point out the slow growth, a low thickening of the passive film followed by a stable passive state $[17,18]$; the values of $\mathrm{E}_{\mathrm{oc}}$ for Ti are placed on a Pourbaix diagram [9] in the passive potential range; namely, Ti is passive.

For Ti-6Al-4V alloy, the open circuit potentials have some oscillations at the beginning, reflecting that its passive film is not completely stable [17,18]; after about 500 immersion hours, $\mathrm{E}_{\mathrm{OC}}$ values slowly move to more electropositive values and then stabilize to about $-100 \mathrm{mV}$ (vs. SCE), fact that ascertains a stable passive film $[17,18]$, taking into account that all its constituent elements $\mathrm{Ti}, \mathrm{Al}, \mathrm{V}$ are placed in their passive potential range on Pourbaix diagrams [9]. 
The novel Ti-23Hf-3Mo-4Sn alloy presents the most electropositive values of its open circuit potentials; these $E_{\mathrm{oc}}$ values tend to have nobler values in time, reaching a value of $-80 \mathrm{mV}$ (vs. SCE) after 1000 exposure hours in SBF; this behavior reveals a more resistant passive state, namely, the passive film thickened in time and improved its protective properties $[17,18]$; this fact is normal because all alloying elements Ti, Hf, Sn, Mo find out in their passive state on Pourbaix diagrams [9]. In addition, the new alloy native passive film being thicker than that of the CP-Ti and Ti-6Al-4V alloy confers the best corrosion resistance [25].

From the monitoring of the open circuit potentials, the results showed that the new Ti-23Hf-3Mo-4Sn alloy has the noblest, stable passive behavior.

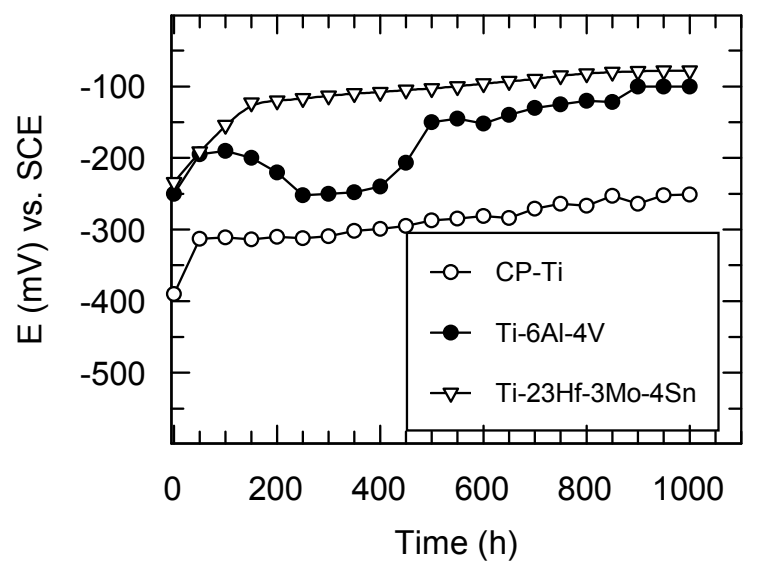

Figure 7. Monitoring of the open circuit potentials for CP-Ti, Ti-6Al-4V and Ti-23Hf-3Mo-4Sn alloy in SBF at $37^{\circ} \mathrm{C}$.

\subsection{In Vitro Behavior of Human Umbilical Vein Endothelial Cells}

\subsubsection{Cell Viability/Proliferation}

The aim of in vitro research was to assess the biological performance of the new Ti-23Hf-3Mo-4Sn alloy in comparison to commonly used metallic biomaterials CP-Ti and Ti-6Al-4V. Quantification of metabolically active cells was performed for two time points by means of the MTT (3-[4,5-dimethylthiazol-2-yl]-2,5 diphenyl tetrazolium bromide) assay. Results demonstrated an increase in cell proliferation from day 1 to day 3 for all samples (Figure 8). Statistically significant differences among the three groups were not identified. These results demonstrate that the Ti-23Hf-3Mo-4Sn alloy support HUVEC attachment and proliferation.

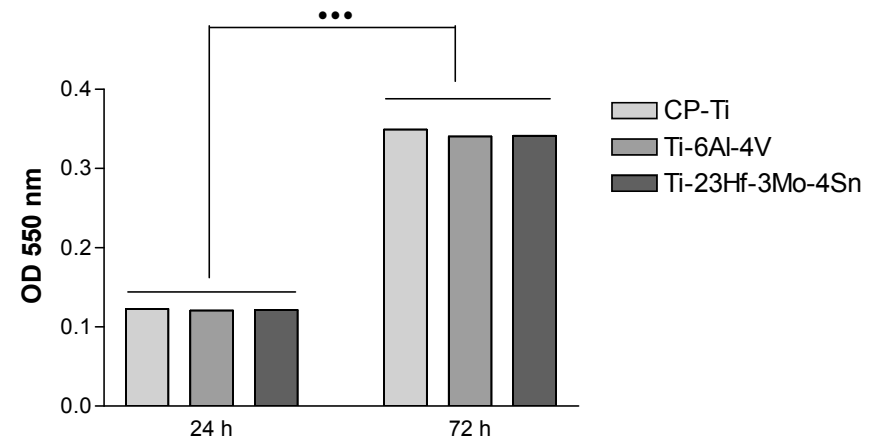

Figure 8. Influence of the test samples on cell proliferation rates as assayed using the MTT colorimetric method. Results demonstrate a time-dependent increase in cell proliferation rate without significant differences between cells growing on the analyzed materials at a certain time point. Data analysis was based on mean $\pm \operatorname{SD}(n=3) . \bullet \bullet p<0.001$ between respective groups at $72 \mathrm{~h}$ vs. $24 \mathrm{~h}$. 


\subsubsection{Expression of the Endothelial Cell Functional Markers}

Besides cell viability and cell proliferation, considerations of cell phenotype are also important to evaluate cellular response to biomaterials. Therefore, the expression of von Willebrand factor (vWf) and VE-cadherin, specific endothelial cell markers [37,38], was next investigated in order to test whether HUVECs on analyzed materials could maintain a normal endothelial phenotype. The expression and cellular localization of $\mathrm{vWf}$ and VE-cadherin were analyzed by immunofluorescence at three days post-seeding. A dotted pattern of vWf was observed within the cytoplasm, mostly in the perinuclear region, in the case of all samples. As shown in Figure 9, cells grown on Ti-23Hf-3Mo-4Sn alloy had similar vWf expression to the cells grown on control samples. Taken together, these results suggest that the newly developed alloy promotes endothelial cell adhesion and proliferation with functional vWf marker expression.
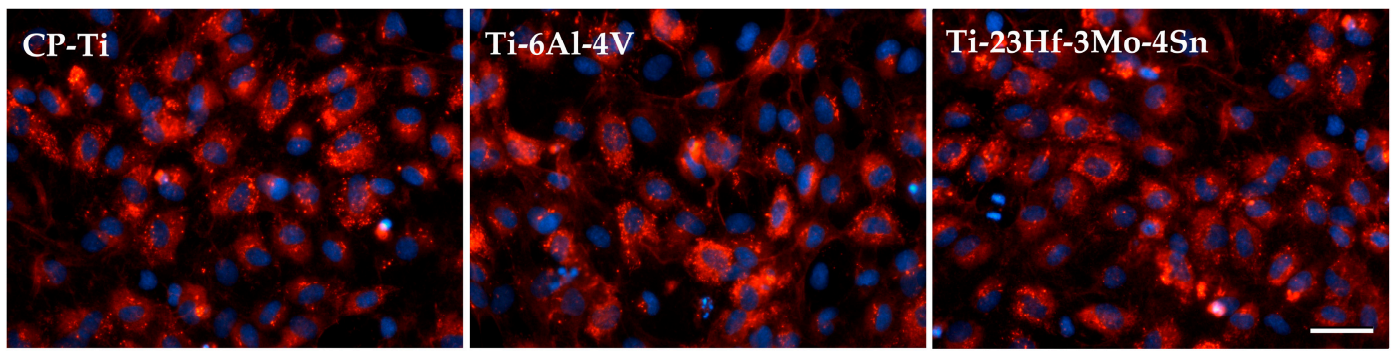

Figure 9. Fluorescent microscopy images of HUVECs cultured for $72 \mathrm{~h}$ on CP-Ti, Ti-6Al-4V and Ti-23Hf-3Mo-4Sn surfaces. vWf and cell nuclei were stained red and blue, respectively. Scale bar represents $50 \mu \mathrm{m}$.

Further on, high resolution fluorescence images revealed the expression of VE-cadherin, which was localized to the cell-cell contacts and showed a continuous line of immunofluorescence describing the outer periphery of cells (Figure 10). These results also indicate the preservation of endothelial cells characteristic phenotype on the new alloy.
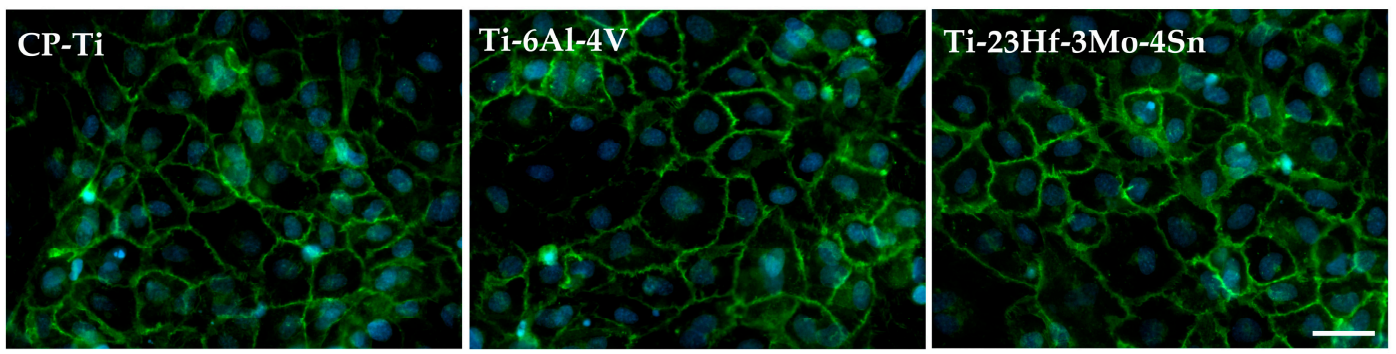

Figure 10. Fluorescent microscopy images of HUVECs cultured for $72 \mathrm{~h}$ on CP-Ti, Ti-6Al-4V and Ti-23Hf-3Mo-4Sn surfaces. VE-cadherin and cell nuclei were stained green and blue, respectively. Scale bar represents $50 \mu \mathrm{m}$.

Another important indicator used to assess the function of endothelial cells adhered to the surface of biomaterials is represented by nitric oxide (NO) production. NO is synthesized continuously by healthy endothelial cells and has a pivotal role in the regulation of vascular tone, vasomotor function, inhibition of leukocyte adhesion to the endothelium, maintaining vascular smooth muscle cells in a non-proliferative state and limiting platelet aggregation [39]. In this study, the level of NO released by the endothelial cells grown on metallic substrates for $72 \mathrm{~h}$ was examined by measuring the level of nitrite accumulation in the cell culture media. The results, shown in Figure 11, do not display statistically significant differences between analyzed samples. 


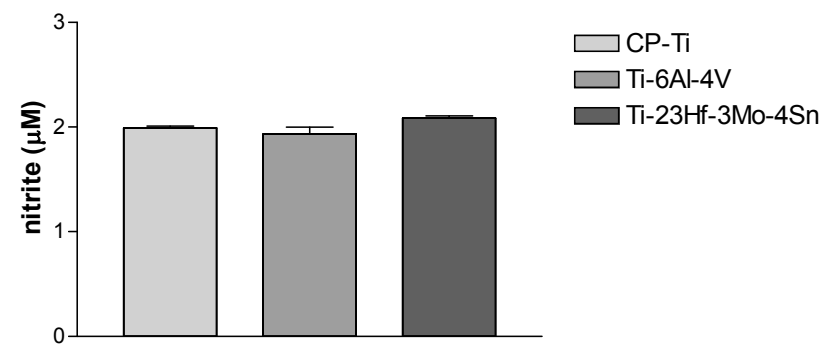

Figure 11. Nitrite concentrations in the cell culture media of HUVECs grown on CP-Ti, Ti-6Al-4V and Ti-23Hf-3Mo-4Sn alloy, as assessed by Griess reagent assay. Data are presented as mean $\pm \mathrm{SD}(n=3)$.

\section{Materials and Methods}

\subsection{Alloy Synthesis}

The Ti-23Hf-3Mo-4Sn (at \%) ingot was synthesized by cold crucible levitation melting (CCLM) under vacuum, by using a high frequency magnetic induction generator heating system. After melting, a homogenization annealing was performed in the $\beta$-phase domain at $1223 \mathrm{~K}$ for $72 \mathrm{ks}$ under high vacuum $\left(\sim 10^{-7} \mathrm{mbar}\right)$ and then quenched in water. After the homogenization step, the ingot was cold rolled up to a reduction level larger than $95 \%$ of the initial thickness without intermediate annealing. The final thickness of the cold rolled sheet was about $0.5 \mathrm{~mm}$. Then, disc samples (diameter of about $1.3 \mathrm{~cm}$ ) were cut from the cold rolled sheet. All samples were then solution treated under high vacuum $\left(\sim 10^{-7} \mathrm{mbar}\right)$ at $1073 \mathrm{~K}$ for $1.8 \mathrm{ks}$ and water quenched at room temperature. Before XPS analysis, electrochemical characterizations and biocompatibility assessment, samples were first mechanically polished on silicon carbide abrasive papers followed by a final mirror polishing step with a colloidal silica suspension (particles size: $50 \mathrm{~nm}$ ). Roughness of the mirror polished samples was evaluated by atomic force microscopy scans taken in different zones of the surface (AFM, CSM Instrument, tapping mode with a silicon tip).

\subsection{Alloy Native Passive Film Characterization}

XPS technique was used to determine the composition and the thickness of the native passive film existing on the Ti-23Hf-3Mo-4Sn alloy surface. Quantera SXM equipment (Physical Electronics, ULVAC-PHI, Minneapolis, MN, USA) has as an X-ray source, AlK $\alpha$ radiation $(1486.6 \mathrm{eV}$, monochromatized) and an overall energy resolution of $0.75 \mathrm{eV}$ by the full width at half maximum of the $\mathrm{Au} 4 \mathrm{f}_{7 / 2}$ line. The spectra were calibrated using the $\mathrm{C} 1 \mathrm{~s}$ line. The errors in the quantitative analysis (relative concentration) were estimated at $\pm 10 \%$ and the accuracy of Binding Energy (BE) assignment was $\pm 2 \mathrm{eV}$. Before beginning the experiments, a gentle Ar+ ion etching $(1 \mathrm{KeV})$ was applied for $0.2 \mathrm{~min}$ aiming to remove the unavoidable surface contaminants and avoid disturbing the surface chemistry.

The oxide thicknesses were calculated by using the sputter rates reported by Baer et al. [14] on a very similar instrument, PHI Quantum 2000 (Physical Electronics, ULVAC-PHI, Minneapolis, MN, USA). To maximize the accuracy of the estimated thicknesses, we used the same setup parameters as in the above-mentioned paper: $2 \mathrm{keV} \mathrm{Ar}{ }^{+}$ion beam, $2 \times 2 \mathrm{~mm}^{2}$ rastered area, $45^{\circ}$ incident angle, and $200 \mu \mathrm{m}$ spot size diameter. These data were corrected for the escape depth (inelastic mean free path) of the photoelectrons as a function of the kinetic energy.

\subsection{Electrochemical Characterization}

The disc samples were mirror polished and sonochemically degreased in acetone and bi-distilled water for every $30 \mathrm{~min}$, dried in air and then mounted in a tight hold system, and a surface of about $1 \mathrm{~cm}^{2}$ was exposed to SBF. The cation and anion concentrations (mmol/L) of SBF in comparison with blood plasma are presented in Table 6. The temperature was kept at $37^{\circ} \mathrm{C} \pm 1{ }^{\circ} \mathrm{C}$. 
Table 6. Ion concentrations (mmol/L) of SBF and human blood plasma.

\begin{tabular}{ccc}
\hline Ion & Simulated Body Fluid & Blood Plasma \\
\hline $\mathrm{Na}^{+}$ & 142.0 & 142.0 \\
$\mathrm{~K}^{+}$ & 5.0 & 5.0 \\
$\mathrm{Mg}^{2+}$ & 1.5 & 1.5 \\
$\mathrm{Ca}^{2+}$ & 2.5 & 2.5 \\
$\mathrm{Cl}^{-}$ & 148.8 & 103.0 \\
$\mathrm{HCO}_{3}{ }^{-}$ & 4.2 & 27.0 \\
$\mathrm{HPO}_{4}{ }^{2-}$ & 1.0 & 1.0 \\
$\mathrm{SO}_{4}{ }^{2-}$ & 0.5 & 0.5 \\
\hline
\end{tabular}

Three types of the electrochemical polarization tests, cyclic and linear potentiodynamic polarization and EIS were used to determine the passivity and corrosion behavior of the new Ti-23Hf-3Mo-4Sn alloy in comparison with CP-Ti and Ti-6Al-4V alloy. Additionally, the open circuit potentials, $\mathrm{E}_{\mathrm{oc}}$ were monitored for 1000 immersion hours in SBF (using a performing Hewlett-Packard multimeter=HP34401A, Hewlett-Packard, Palo Alto, CA, USA) to study the materials' long-term behavior.

The cyclic potentiodynamic polarization was performed from $-800 \mathrm{mV}$ (vs. SCE) till $+1000 \mathrm{mV}$ (vs. SCE) with a scan rate of $1 \mathrm{mV} / \mathrm{s}$. Voltalab 80 equipment (Radiometer Analytical, Loveland, CO, USA) with its VoltaMaster 4 program (version 7.09, Radiometer Analytical, Loveland, CO, USA) provided the cyclic voltammograms and the following electrochemical parameters: corrosion potential, $\mathrm{E}_{\mathrm{corr}}-$ zero current potential; passivation potential, $\mathrm{E}_{\mathrm{p}}-$ potential for the constant passive current; tendency to passivation, $\left|E_{\text {corr }}-E_{p}\right|-$ low values indicate a very good, easy passivation; passive potential range $\Delta \mathrm{E}_{\mathrm{p}}$ - the domain of the constant passive current; passive current density, and $i_{p}-$ current density value in the passive potential range. The passive state is characterized by lower values of the current densities on the reverse curve than those on the direct curve; the pitting corrosion is evinced by higher values of the current density on the reverse curve than those on the direct curve [40,41].

The linear polarization was carried-out (with the same Voltalab 80 equipment) for $\pm 150 \mathrm{mV}$ around the open circuit potential using a scan rate of $0.1 \mathrm{mV} / \mathrm{s}$ and the VoltaMaster 4 program supplied from Tafel representations of the following corrosion parameters: corrosion current density $-\mathrm{i}_{\text {corr }}$; corrosion rate $-\mathrm{V}_{\text {corr }}$; polarization resistance $-\mathrm{R}_{\mathrm{p}}$; anodic $-\beta_{\mathrm{a}}$ and cathodic $-\beta_{\mathrm{c}}$ Tafel slopes.

EIS was applied with the same Voltalab 80 equipment. Nyquist and Bode spectra were recorded at open circuit potential using a potential signal of $7 \mathrm{mV}$ in a frequency range from $10^{-1} \mathrm{~Hz}$ to $10^{5} \mathrm{~Hz}$. The impedance spectra were analyzed by the ZView program (version 3.5a, Scribner Associates Inc., Southern Pines, NC, USA) and an electric equivalent circuit was fitted.

Three samples were used in experiments and the result reproducibility was very good.

\subsection{Cell Culture}

HUVEC cells, purchased from American Type Culture Collection (ATCC), LGC Standards $\mathrm{GmbH}$, Wesel, Germany, were maintained in F-12K Medium (Kaighn's Modification of Ham's F-12 Medium) supplemented with 10\% fetal bovine serum (Gibco, Grand Island, NY, USA), $1 \%$ penicillin-streptomycin (Gibco) and $30 \mu \mathrm{g} / \mathrm{mL}$ endothelial cell growth supplement (Sigma-Aldrich Co., St. Louis, MO, USA) at $37{ }^{\circ} \mathrm{C}$ in $5 \% \mathrm{CO}_{2}$. At approximately $80 \%$ confluence, the cells were trypsinized and seeded onto the substrates for cell behavior studies at a density of $10^{4} \mathrm{cells} / \mathrm{cm}^{2}$. These studies have been conducted with cells from passage 4 to 6 . Prior to cell seeding, samples were sterilized by soaking in 70\% ethanol for $30 \mathrm{~min}$. Then, the samples were rinsed twice for $30 \mathrm{~min}$ in sterile-filtered MilliQ (Merck Millipore, Darmstadt, Germany) water, air dried and exposed to ultraviolet light in a sterile tissue culture hood, for $30 \mathrm{~min}$ on each side. 


\subsection{Cell Proliferation}

Proliferation of HUVECs was monitored at $24 \mathrm{~h}$ and $72 \mathrm{~h}$, using MTT assay. Briefly, cell monolayers were incubated with MTT solution $\left(1 \mathrm{mg} / \mathrm{ml}\right.$ in serum free culture medium) for $3 \mathrm{~h}$ at $37^{\circ} \mathrm{C}$. Then, the MTT solution was decanted and formazan crystals were solubilized with dimethyl sulfoxide. Absorbance of the dye was measured at a wavelength of $550 \mathrm{~nm}$ and recorded using a microplate reader (Thermo Scientific Appliskan, Vantaa, Finland).

\subsection{Immunocytochemical Staining of HUVECs Grown on Ti-23Hf-3Mo-4Sn Alloy}

The expression of $\mathrm{vWf}$ and VE-cadherin within HUVEC grown on Ti-23Hf-3Mo-4Sn and control surfaces was examined using immunocytochemical staining. Following a $72 \mathrm{~h}$ growth period on the samples, the culture media were removed and the cells were washed and fixed by immersion in $4 \%$ paraformaldehyde. Following fixation, the cells were permeabilized by incubating with $0.1 \%$ Triton X-100 (Sigma-Aldrich Co., St. Louis, MO, USA) in PBS (phosphate-buffered saline), and blocked in PBS containing $2 \%$ bovine serum albumin. The samples were then incubated with mouse anti-human vWf monoclonal antibody (Santa Cruz Biotechnology, Dallas, TX, USA) or mouse anti-human VE-cadherin monoclonal antibody (Santa Cruz Biotechnology) in PBS containing 1.2\% BSA (bovine serum albumin). After washing with PBS, they were further incubated with Alexa Fluor 546-conjugated goat anti-mouse IgG antibody (Molecular Probes, Eugene, OR, USA) and Alexa Fluor 488-conjugated goat anti-mouse IgG antibody ( Molecular Probes), respectively, in PBS containing 1.2\% BSA, followed by washing with PBS. A $2 \mu \mathrm{g} / \mathrm{mL}$ DAPI (4'6-diamidino-2- phenylindole) solution was used to stain cell nuclei. Fluorescent images were taken with an Olympus IX71 inverted microscope (Olympus, Tokyo, Japan).

\subsection{NO Release Assay}

To detect the release of NO, HUVECs were seeded onto substrates placed in 24 well plates at a density of $5 \times 10^{4}$ cells $/ \mathrm{cm}^{2}$. After 3 days of culture, the supernatants of each well were collected. The relative content of $\mathrm{NO}$ in the supernatants was measured as previously described [42].

\subsection{Statistical Analysis}

For the statistical analysis of the MTT and NO release assays, one-way ANOVA with Bonferroni's multiple comparison tests (GraphPad Prism software, Version 3.03, GraphPad, San Diego, CA, USA) was performed. A probability of $p<0.05$ was considered significant.

\section{Conclusions}

XPS survey spectra acquired on the novel Ti-23Hf-3Mo-4Sn alloy surface showed that the thickness of the native passive film is of $\sim 18.0 \mathrm{~nm}$.

The deconvoluted spectra evinced that this surface film consisted of protective $\mathrm{TiO}_{2}, \mathrm{Ti}_{2} \mathrm{O}_{3}, \mathrm{HfO}_{2}$; $\mathrm{MoO}_{2}$, and $\mathrm{SnO}_{2}$ oxides. The thicknesses of the individual oxides are quite different, $\mathrm{HfO}_{2}$ being the main contributor to the overall thickness of the film on the alloy surface.

The values of all the electrochemical parameters prove a nobler electrochemical behavior of the new superelastic Ti-23Hf-3Mo-4Sn alloy by comparison with CP-Ti and Ti-6Al-4V alloy. This behavior is ascribed to the favorable influence of the alloying elements $\mathrm{Hf}, \mathrm{Sn}$, and Mo which enhanced the protective properties of the alloy native passive film. All corrosion parameters for the new alloy confirm a higher protective capacity that prevents the dissolution of the alloy substrate in comparison with commercial materials CP-Ti and Ti-6Al-4V alloy.

Nyquist and Bode impedance spectra characterized a passive film with two layers, namely an inner, capacitive, barrier, compact layer and an outer, less protective, porous layer; these two layers confer both protection and bioactivity to the alloy.

Monitoring of the open circuit potentials resulted in the new Ti-23Hf-3Mo-4Sn alloy having the noblest, stable behavior, and more resistant passive film than those in the reference materials. 
Ti-23Hf-3Mo-4Sn surface displayed excellent endothelial cell growth. Moreover, HUVEC cells retained their phenotype and functions as revealed by $\mathrm{vWf}, \mathrm{VE}-$ cadherin expressions and NO assay.

Overall, the results obtained in the present study demonstrate that this new superelastic Ti-23Hf-3Mo-4Sn alloy represents a promising material for various medical devices, particularly for the manufacture of self-expanding vascular stents or superelastic catheters for which a perfect biocompatibility and a large recovery strain are required.

Acknowledgments: This study was financially supported by the French National Research Agency (project ANR-13-IS09-0008-01) and by a research grant from the Romanian Ministry of National Education, CNCS-UEFISCDI (project PN-II-ID-20-RO-FR-2014).

Author Contributions: The research work presented in this paper was carried out in the framework of an international collaborative project. The project team consists of four supervisors, A.C., T.G., D.-M.G. and C.V., and four researchers, R.I., S.I.D., P.O. and M.F.I. The four supervisors have provided the original idea, supervised the research work and contributed to the design of the manuscript. M.F.I. synthetized the Ti-23Hf-3Mo-4Sn alloy, C.V. conducted the electrochemical experiments, S.I.D. effectuated the cyclic and linear measurements and EIS; P.O. carried out XPS analysis and result interpretation, and R.I. performed biological experiments. All authors were involved in the results discussion and in finalizing the manuscript. A.C. edited the manuscript.

Conflicts of Interest: The authors declare no conflict of interest.

\section{References}

1. Niinomi, M.; Nakai, M.; Hieda, J. Development of new metallic alloys for biomedical applications. Acta Biomater. 2012, 8, 3888-3903. [CrossRef] [PubMed]

2. Kim, H.Y.; Ikehara, Y.; Kim, J.I.; Hosoda, H.; Miyazaki, S. Martensitic transformation, shape memory effect and superelasticity of Ti-Nb binary alloys. Acta Mater. 2006, 54, 2419-2429. [CrossRef]

3. Hao, Y.L.; Li, S.J.; Sun, S.Y.; Yang, R. Effect of Zr and Sn on Young's modulus and superelasticity of Ti-Nb-based alloys. Mater. Sci. Eng. A 2006, 441, 112-118. [CrossRef]

4. Castany, P.; Gordin, D.M.; Drob, S.I.; Vasilescu, C.; Mitran, V.; Cimpean, A.; Gloriant, T. Deformation mechanisms and biocompatibility of the superelastic Ti-23Nb-0.7Ta-2Zr-0.5N alloy. Shape Mem. Superelast. 2016, 2, 18-28. [CrossRef]

5. Castany, P.; Ramarolahy, A.; Prima, F.; Laheurte, P.; Curfs, C.; Gloriant, T. In situ synchrotron X-ray diffraction study of the martensitic transformation in superelastic Ti-24Nb-0.5N and Ti-24Nb-0.5O alloy. Acta Mater. 2015, 88, 102-111. [CrossRef]

6. Fu, J.; Yamamoto, A.; Kim, H.Y.; Hosoda, H.; Miyazaki, S. Novel Ti-base superelastic alloys with large recovery strain and excellent biocompatibility. Acta Biomater. 2015, 17, 56-67. [CrossRef] [PubMed]

7. Ijaz, M.F.; Kim, H.Y.; Hosoda, H.; Miyazaki, S. Superelastic properties of biomedical (Ti-Zr)-Mo-Sn alloys. Mater. Sci. Eng. C Mater. Biol. Appl. 2015, 48, 11-20. [CrossRef] [PubMed]

8. Ijaz, M.F.; Laillé, D.; Héraud, L.; Gordin, D.M.; Castany, P.; Gloriant, T. Design of a novel superelastic Ti-23Hf-3Mo-4Sn biomedical alloy combining low modulus, high strength and large recovery strain. Mater. Lett. 2016, 177, 39-41. [CrossRef]

9. Pourbaix, M. Atlas of Electrochemical Equilibria in Aqueous Solutions; Natl Assn of Corrosion Engineers: Houston, TX, USA, 1974.

10. Niinomi, M. Low modulus titanium alloys for inhibiting bone atrophy. In Biomaterials Science and Engineering; Pignatello, R., Ed.; In Tech: Rijeka, Croatia, 2011; pp. 249-268. Available online: http://www.intechopen. com/books (accessed on 20 May 2016).

11. Jeong, Y.-H.; Lee, K.; Choe, H.-C.; Ko, Y.-M.; Brantley, W.A. Nanotube formation and morphology change of Ti alloys containing Hf for dental materials use. Thin Solid Films 2009, 517, 5365-5369. [CrossRef]

12. Moon, B.-H.; Choe, H.-C.; Brantley, W.A. Surface characteristics of TiN/ZrN coated nanotubular structure on the Ti-35Ta-xHf alloy for bio-implant applications. Appl. Surf. Sci. 2012, 258, 2088-2092. [CrossRef]

13. Rogal, L.; Czerwinski, F.; Jochym, P.T.; Litynska-Dobrzynska, L. Microstructure and mechanical properties of the novel Hf25Sc25Ti25Zr25 equiatomic alloy with hexagonal solid solutions. Mater. Des. 2016, 92, 8-17. [CrossRef] 
14. Baer, D.R.; Egelhard, M.H.; Lea, A.S.; Nachimuthu, P.; Drobay, T.C.; Kin, J.; Lee, B.; Mathews, C.; Opila, R.L.; Saraf, L.V.; et al. Comparison of the sputter rates of the oxide films relative to the sputter rate of $\mathrm{SiO}_{2}$. J. Vac. Sci. Technol. A 2010, 28, 1060-1072. [CrossRef]

15. Naumkin, A.V.; Kraut-Vass, A.; Gaarenstroom, A.; Powell, C.J. NIST X-ray Photoelectron Spectroscopy Database. In NIST Standard Reference Database 20, version 4.1; National Institute of Standards and Technology: Gaithersburg, MD, USA, 2012.

16. Moulder, J.F.; Stickle, W.F.; Sobol, P.E.; Bomben, K.D. Handbook of X-ray Photoelectron Spectroscopy; Physical Electronics USA, Inc.: Chamhassen, MN, USA, 1995.

17. Black, J. Biological Performance of Materials: Fundamentals of Biocompatibility; M. Decker Inc.: New York, NY, USA, 1992.

18. Blackwood, D.J.; Chua, A.W.C.; Seah, K.H.W.; Thampuran, R. Corrosion behaviour of porous titanium-graphite composite designed for surgical implants. Corros. Sci. 2000, 42, 481-503. [CrossRef]

19. Wang, B.L.; Zheng, Y.F.; Zhao, L.C. Electrochemical corrosion behavior of biomedical Ti-22Nb and Ti-22Nb-6Zr alloys in saline medium. Mater. Corros. 2009, 60, 788-794. [CrossRef]

20. Woldemedhin, M.T.; Raabe, D.; Hassel, A.W. Characterization of thin oxides of Ti-Nb alloys by electrochemical impedance spectroscopy. Electrochim. Acta 2012, 82, 324-332. [CrossRef]

21. Milosev, I.; Metikos-Hukovic, M.; Strenhblw, H.-H. Passive film on orthopaedic TiAlV alloy formed in physiological solution by X-ray photoelectron spectroscopy. Biomaterials 2000, 21, 2103-2113. [CrossRef]

22. Vasilescu, E.; Drob, P.; Raducanu, D.; Cinca, I.; Mareci, D.; Calderon Moreno, J.M.; Popa, M.; Vasilescu, C.; Mirza Rosca, J.C. Effect of thermo-mechanical processing on the corrosion resistance of Ti6Al4V alloys in biofluids. Corros. Sci. 2009, 51, 2885-2896. [CrossRef]

23. Mansfeld, F. Simultaneous determination of instantaneous corrosion rates and Tafel slopes from polarization resistance measurements. J. Electrochem. Soc. 1973, 120, 515-518. [CrossRef]

24. Jones, D. Principles and Prevention of Corrosion, 2nd ed.; Prentice-Hall Inc.: Upper Saddle River, NJ, USA, 1995.

25. Li, J.; Yang, L.; Ma, H.; Jiang, K.; Chang, C.; Wang, J.-Q.; Song, Z.; Wang, X.; Li, R.-W. Improved corrosion resistance of novel Fe-based amorphous alloys. Mater. Des. 2016, 95, 225-230. [CrossRef]

26. Robin, A.; Carvalho, O.A.S.; Schneider, S.G.; Schneider, S. Corrosion behavior of Ti-xNb-13Zr alloys in Ringer's solution. Mater. Corros. 2008, 59, 929-933. [CrossRef]

27. Milosev, I.; Zerjav, G.; Calderon Moreno, J.M.; Popa, M. Electrochemical properties, chemical composition, and thickness of passive film formed on novel Ti-20Nb-10Zr-5Ta alloy. Electrochim. Acta 2013, 99, 176-189. [CrossRef]

28. Robin, A.; Mierelis, J.P. Influence of fluoride concentration and $\mathrm{pH}$ on corrosion behaviour of Ti-6Al-4V and Ti-23Ta alloys in artificial saliva. Mater. Corros. 2007, 58, 173-180. [CrossRef]

29. Assis, S.L.; Wolynec, S.; Costa, I. Corrosion characterization of titanium alloys by electrochemical techniques. Electrochim. Acta 2006, 51, 1815-1819. [CrossRef]

30. Cremasco, A.; Osorio, W.R.; Freire, C.M.A.; Garcia, A.; Caram, R. Electrochemical corrosion behavior of a Ti-35Nb alloy for medical prostheses. Electrochim. Acta 2008, 53, 4867-4874. [CrossRef]

31. Alves, V.A.; Reis, R.Q.; Santos, I.C.B.; Souza, D.G.; Goncleves, T.F.; Pereira-da-Silva, M.A.; Rossi, A.; da Silva, L.A. In situ impedance spectroscopy study of the electrochemical corrosion of Ti and Ti-6Al-4V in simulated body fluid at $25^{\circ} \mathrm{C}$ and $37^{\circ} \mathrm{C}$. Corros. Sci. 2009, 51, 2473-2482. [CrossRef]

32. Tamilselvi, S.; Rajendran, N. In vitro corrosion behaviour of Ti-5Al-2Nb-1Ta alloy in Hanks solution. Mater. Corros. 2007, 58, 285-289. [CrossRef]

33. Martins, D.Q.; Osório, W.R.; Souza, M.E.P.; Caram, R.; Garcia, A. Effects of Zr content on microstructure and corrosion resistance of Ti-30Nb-Zr casting alloys for biomedical applications. Electrochim. Acta 2008, 53, 2809-2817. [CrossRef]

34. Souto, R.M.; Laz, M.M.; Reis, R.L. Degradation characteristics of hydroxyapatite coatings on orthopaedic TiAlV in simulated physiological media investigated by electrochemical impedance spectroscopy. Biomaterials 2003, 24, 4213-4221. [CrossRef]

35. Lavos-Valereto, I.C.; Wolynec, S.; Ramires, I.; Guastaldi, A.C.; Costa, I. Electrochemical impedance spectroscopy characterization of passive film formed on implant Ti-6Al-7Nb alloy in Hank's solution. J. Mater. Sci. Mater. Med. 2004, 15, 55-59. [CrossRef]

36. Osorio, W.S.R.; Goulart, P.R. Effect of dendritic arm spacing on mechanical properties and corrosion resistance of Al 9 Wt Pct Si and Zn 27 Wt Pct Al alloys. Metall. Mater. Trans. 2006, 37, 2525-2538. [CrossRef] 
37. Giannotta, M.; Trani, M.; Dejana, E. VE-Cadherin and endothelial adherens junctions: Active guardians of vascular integrity. Dev. Cell 2013, 26, 441-454. [CrossRef] [PubMed]

38. Santos, M.I.; Fuchs, S.; Gomes, M.E.; Unger, R.E.; Reis, R.L.; Kirkpatrick, C.J. Response of micro- and macrovascular endothelial cells to starch-based fiber meshes for bone tissue engineering. Biomaterials 2007, 28, 240-248. [CrossRef] [PubMed]

39. Zhong, S.; Luo, R.; Wang, X.; Tang, L.L.; Wu, J.; Wang, J.; Huang, R.; Sun, H.; Huang, N. Effects of polydopamine functionalized titanium dioxide nanotubes on endothelial cell and smooth muscle cell. Colloids Surf. B Biointerfaces 2014, 116, 553-560. [CrossRef] [PubMed]

40. Burstein, G.T.; Liu, C.; Souto, R.M. The effect of temperature on the nucleation of corrosion pits on titanium in Ringer's physiological solution. Biomaterials 2005, 26, 245-256. [CrossRef] [PubMed]

41. Burstein, G.T.; Souto, R.M. Improvement in pitting resistance of stainless steel surfaces by prior anodic treatment in metasilicate solution. J. Electrochem. Soc. 2004, 151, B537-B542. [CrossRef]

42. Neacsu, P.; Mazare, A.; Cimpean, A.; Park, J.; Costache, M.; Schmuki, P.; Demetrescu, I. Reduced inflammatory activity of RAW 264.7 macrophages on titania nanotube modified Ti surface. Int. J. Biochem. Cell Biol. 2014, 55, 187-195. [CrossRef] [PubMed]

(C) 2016 by the authors; licensee MDPI, Basel, Switzerland. This article is an open access article distributed under the terms and conditions of the Creative Commons Attribution (CC-BY) license (http:/ / creativecommons.org/licenses/by/4.0/). 